\title{
Element contents in muscle tissue of Prussian carp from different lakes in an urban area
}

\author{
Dragoljub Jovanovic ${ }^{1}$, Vlado Teodorovic ${ }^{1}$, Radmila Markovic ${ }^{1}$, Milena Krstic ${ }^{1}$, Jelena Ciric ${ }^{2 *}$, \\ Milan Z. Baltic ${ }^{1}$ Branislav Baltic ${ }^{2}$, Dragan Sefer ${ }^{1}$
}

A b s tr a c t: The aim of this study was to determine the content of some elements ( $\mathrm{Pb}, \mathrm{Cd}, \mathrm{Hg}, \mathrm{Fe}, \mathrm{Cu}, \mathrm{Zn}, \mathrm{As}$ ) in muscle tissue of Prussian carp (Carassius auratus gibelio) from seven different lakes in the Belgrade region, Serbia. Concentrations of Pb, Hg and As in fish muscle tissues from all examined lakes were under the maximum residual levels prescribed by the European Union (EU) and the maximum allowed concentrations (MAC) for Serbia. In all investigated fish, levels of Cd exceeded maximum allowed concentrations $\left(0.05 \mathrm{mg} \mathrm{kg}^{-1}\right)$. Data on the finding of elements in fish speak concurrently about the safety of fish as food and are good indicators of environmental pollution.

Key words: Elements, Prussian carp, Lakes, Contamination.

\section{Introduction}

In human diets, fish present a significant place as a biologically valuable food. Because of their nutritional value, fish meat and fish products have an important role in proper nutrition and health protection for all categories of people (Sidhu, 2003). Fish's nutritional value is primarily reflected in easily digestible proteins that have a high content of essential amino acids, the high content of $\omega-3$ polyunsaturated fatty acids, and low fat and cholesterol contents. Fish also contains other nutritional ingredients (vitamins, minerals) important for human nutrition (Kminkova, 2001). On the one hand, fish has favorable influences on brain activity, prevention and reduction of cardiovascular diseases, inflammatory joint processes, and prevention and treatment of cancer (Mayneris-Perxachs et al., 2010). On the other hand, fish, like other foods, can endanger consumers' health when it contains harmful chemical compounds. Hazards from the group of industrial-chemical pollutants include toxic metals and organic chemical contaminants (Elia et al., 2007). In order to protect consumer health, the amount of toxic metals in food and in fish is limited by regulation in most countries. The regulations primarily refer to mercury, lead, cadmium and arsenic, and in some cases to other elements such as zinc, tin, copper and iron, the quantities of which are limited in in canned fish products. However, industrial development and inappropriate environmental measures have resulted in increased presence of toxic metals in the environment (Kosior et al., 2018). Increased concentrations of metals, mostly mercury, lead and cadmium, were recorded in freshwater fish from open waters, as a result of the fact that metal concentrations in water are positively correlated with their concentrations in fish tissue (Castro-Gonzalez et al., 2008). Numerous studies indicate that the concentrations of these metals in different types of fish are beyond permitted levels (Has-Schön et al., 2015, Andreji et al., 2006, Jovanovic et al., 2017), and so could endanger human health. High contents of toxic metals in fish can reduce the cardiovascular effect of fish consumption, and these compounds are associated with serious adverse effects on the health of children and adults (Yoshizawa et al., 2002).

The aims of this study were to determine the contents of seven elements in the muscle tissue of Prussian carp caught from lakes near Belgrade, Serbia, to determine whether the fish was safe as a food for human consumption, and to consider the state of the ecosystems with respect to the metals studied.

\footnotetext{
1 University of Belgrade Faculty of Veterinary Medicine, Bulevar Oslobodjenja 18, 11000 Belgrade, Republic of Serbia;

2Institute of Meat Hygiene and Technology, Kaćanskog 13, Belgrade 11000, Republic of Serbia.
}

*Corresponding author: Jelena Ciric, jelena.ciric@inmes.rs 


\section{Materials and methods}

\section{Study Area and Sampling}

Fish were collected from seven different lakes near Belgrade, Serbia. Lakes Rabrovac, Markovac, Ocaga and Grabovac are located to the south of the city, while Becmen, Veliko Blato and Mokri Sebes are positioned along the geographical longitude north of Belgrade. These locations were selected because of their proximity to important European rivers, the Sava and Danube (which both carry substantial quantities of wastewater), as well as proximity to the urban zone of Belgrade (Figure 1). The fish were caught by professional fishermen at the end of 2017 .

\section{Analysis}

In order to determine elements in 49 (seven from each lake) muscle tissue samples of Prussian carp (Carassius auratus gibelio), all individual fish in each fisherman's haul were identified to species level, and a random sub-sample of 7 individuals at each location was used for metal analysis. Fish were euthanized with an overdose of MS 222 (ethyl ester of p-amino benzoic acid, Sigma Aldrich), and then transported to the laboratory in a refrigerated truck. Fish were dissected, and muscle (ca. 200 g) below the dorsal fin was stored for metal analyses in polypropylene vials previously pre-cleaned with nitric acid (10\%) and rinsed three times in deionized water, and then quickly frozen and stored at $-20^{\circ} \mathrm{C}$. Fish muscles were defrosted at room temperature and mechanically homogenized.

For the determination of elements $(\mathrm{Pb}, \mathrm{Cd}, \mathrm{Hg}$, $\mathrm{As}, \mathrm{Cu}, \mathrm{Fe}$ and $\mathrm{Zn}$ ), fish muscle portions of $1 \pm 0.001$ $\mathrm{g}$ were weighed out. All chemicals used were of analytical grade purity. Fish muscle was digested using a microwave closed system (MW 3000, Anton Paar GmbH, Graz, Austria). Digestion was carried out with a program suitable for preparing samples of fish meat. After digestion, the content of elements was determined by the atomic absorption spectrometry (Perkin Elmer Analyst 700 with the MHS system, Shelton, USA). Quality of analyses was controlled using the certified reference material, ERMBB422 fish muscle. The concentrations determined in the reference material were within the tolerances specified in the delivered certificate.

The element concentrations in fish meat (i.e., muscle) were compared with the maximum allowed concentrations (MAC) in fish meat for utilization in human diets, as established by the European Union (European Commission Regulation, 2006) and the Republic of Serbia (Official Gazette of RS, 2014). According to the EU legislation (European Commission Regulation, 2006), the MACs for $\mathrm{Pb}, \mathrm{Cd}$,

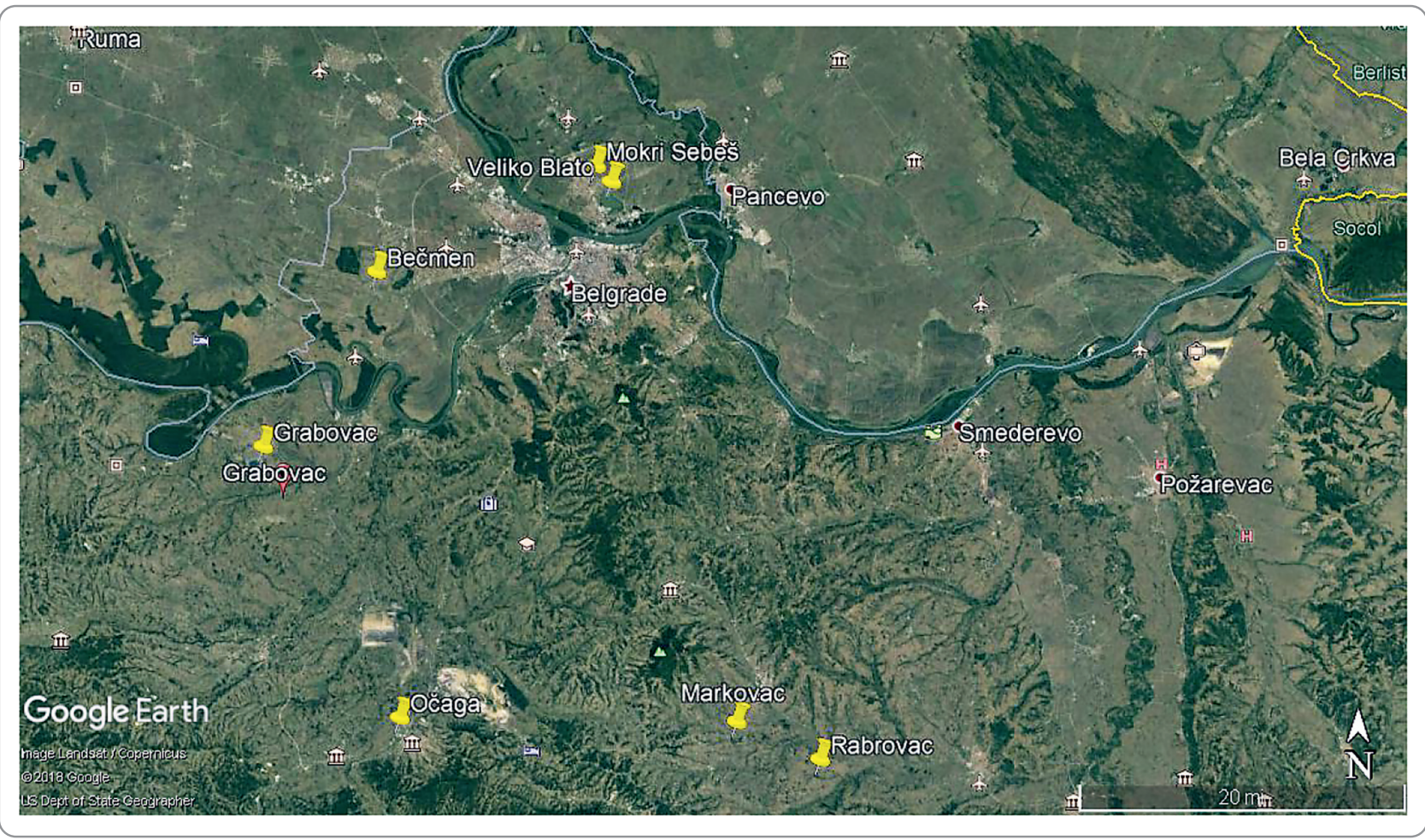

Figure 1. Map of fish collection sites (www. https://earth.google.com) 
$\mathrm{Hg}$ are $0.30,0.05$ and $0.5, \mathrm{mg} \mathrm{kg}^{-1} \mathrm{w} / \mathrm{w}$, respectively. The national legislation (Official Gazette of RS, 2014) is in accordance with the European Commission regulation although it has an additional regulatory MAC for As, with MACs for $\mathrm{Pb}, \mathrm{Cd}, \mathrm{Hg}$, and As being 0.30, $0.05,0.5$, and $2.0 \mathrm{mg} \mathrm{kg}^{-1} \mathrm{w} / \mathrm{w}$, respectively.

All fish muscles were collected and analyzed in duplicate, and the results are expressed as mean \pm standard deviation. Statistical analysis was elaborated using GraphPad Prism version 7.00 software. Statistical analysis was performed using Student's t-test to determine the significance of differences between means. A significance level of $\mathrm{P}<0.05$ was applied.

\section{Results and Discussion}

Element concentrations in muscle tissue of Prussian carp caught from three lakes north of Belgrade are presented in Table 1. The concentrations of $\mathrm{Pb}, \mathrm{Hg}$ and $\mathrm{Cu}$ was significantly higher in muscle tissue of Prussian carp from Veliko Blato than the other sites $(\mathrm{P}<0.05)$. Levels of $\mathrm{Fe}$ were not significant different between Becmen, Veliko Blato and Mokri Sebes $(\mathrm{P}>0.05)$. The $\mathrm{Zn}$ concentration was significantly different $(\mathrm{P}<0.05)$ in different sites and ranged between $5.93 \pm 0.10 \mathrm{mg} \mathrm{kg}^{-1}$ (Mokri Sebes) and $7.91 \pm 0.26 \mathrm{mg} \mathrm{kg}^{-1}$ (Becmen).

The concentration of lead, cadmium, mercury, arsenic, copper, iron and zinc in Prussian carp caught from Lakes Rabrovac, Markovac, Ocaga and Grabovac to the south of Belgrade are shown in Table 2. Concentrations of $\mathrm{Pb}, \mathrm{Cd}, \mathrm{Hg}, \mathrm{As}, \mathrm{Cu}$, $\mathrm{Fe}$ and $\mathrm{Zn}$ in muscle tissue of the Prussian carp from Rabrovac were $0.068 \pm 0.004,0.066 \pm 0.002$, $0.126 \pm 0.005,0.202 \pm 0.005,0.714 \pm 0.010,7.72 \pm 0.12$ and $6.44 \pm 0.10 \mathrm{mg} \mathrm{kg}^{-1}$, respectively. Similar metal concentrations were found in fish muscle from Lake Markovac. No significant differents were found in muscle tissue of the Prussian carp from Rabrovac

Table 1. Element concentrations ( $\mathrm{mg} \mathrm{kg}^{-1} ; \overline{\mathrm{X}} \pm \mathrm{Sd}$ ) in muscle tissue of Prussian carp from three examined lakes north of Belgrade

\begin{tabular}{cccc}
\hline \multirow{2}{*}{ Metal concentration, } & \multicolumn{3}{c}{ Lake } \\
\cline { 2 - 4 } & Bečmen & Veliko Blato & Mokri Sebeš \\
\hline $\mathrm{Pb}$ & $0.036^{\mathrm{a}} \pm 0.004$ & $0.043^{\mathrm{b}} \pm 0.003$ & $0.038^{\mathrm{a}} \pm 0.002$ \\
\hline $\mathrm{Cd}$ & $0.066^{\mathrm{a}} \pm 0.004$ & $0.065^{\mathrm{a}} \pm 0.005$ & $0.059^{\mathrm{b}} \pm 0.004$ \\
\hline $\mathrm{Hg}$ & $0.148^{\mathrm{a}} \pm 0.023$ & $0.223^{\mathrm{b}} \pm 0.017$ & $0.194^{\mathrm{c}} \pm 0.008$ \\
\hline $\mathrm{As}$ & $0.240^{\mathrm{a}} \pm 0.006$ & $0.255^{\mathrm{a}} \pm 0.033$ & $0.276^{\mathrm{b}} \pm 0.015$ \\
\hline $\mathrm{Cu}$ & $0.868^{\mathrm{a}} \pm 0.018$ & $0.875^{\mathrm{a}} \pm 0.014$ & $0.792^{\mathrm{b}} \pm 0.012$ \\
\hline $\mathrm{Fe}$ & $7.76^{\mathrm{a}} \pm 0.27$ & $7.42^{\mathrm{a}} \pm 0.25$ & $7.26^{\mathrm{a}} \pm 0.10$ \\
\hline $\mathrm{Zn}$ & $7.91^{\mathrm{a}} \pm 0.26$ & $6.45^{\mathrm{b}} \pm 0.31$ & $5.93^{\mathrm{c}} \pm 0.10$ \\
\hline
\end{tabular}

Legend: Means (between the same elements from the different sites) within a row with the same letter are not significantly different. a, b, c $\mathrm{P}<0.05$

Table 2. Element concentrations ( $\mathrm{mg} \mathrm{kg}^{-1} ; \overline{\mathrm{X}} \pm \mathrm{Sd}$ ) in muscle tissue of Prussian carp from four examined lakes south of Belgrade

\begin{tabular}{ccccc}
\hline \multirow{2}{*}{ Metal } & \multicolumn{4}{c}{ Lake } \\
\cline { 2 - 5 } & Rabrovac & Markovac & Očaga & Grabovac \\
\hline $\mathrm{Pb}$ & $0.068^{\mathrm{a}} \pm 0.004$ & $0.064^{\mathrm{a}} \pm 0.005$ & $0.026^{\mathrm{b}} \pm 0.005$ & $0.035^{\mathrm{c}} \pm 0.004$ \\
\hline $\mathrm{Cd}$ & $0.066^{\mathrm{a}} \pm 0.002$ & $0.061^{\mathrm{a}} \pm 0.002$ & $0.053^{\mathrm{b}} \pm 0.003$ & $0.061^{\mathrm{a}} \pm 0.009$ \\
\hline $\mathrm{Hg}$ & $0.126^{\mathrm{a}} \pm 0.005$ & $0.119^{\mathrm{a}} \pm 0.008$ & $0.096^{\mathrm{b}} \pm 0.005$ & $0.331^{\mathrm{c}} \pm 0.025$ \\
\hline $\mathrm{As}$ & $0.202^{\mathrm{a}} \pm 0.005$ & $0.190^{\mathrm{a}} \pm 0.004$ & $0.135^{\mathrm{a}} \pm 0.003$ & $0.278^{\mathrm{a}} \pm 0.029$ \\
\hline $\mathrm{Cu}$ & $0.714^{\mathrm{a}} \pm 0.010$ & $0.707^{\mathrm{a}} \pm 0.011$ & $0.789^{\mathrm{a}} \pm 0.021$ & $0.667^{\mathrm{b}} \pm 0.044$ \\
\hline $\mathrm{Fe}$ & $7.72^{\mathrm{a}} \pm 0.12$ & $7.30^{\mathrm{a}} \pm 0.08$ & $7.48^{\mathrm{a}} \pm 0.68$ & $7.00^{\mathrm{a}} \pm 0.14$ \\
\hline $\mathrm{Zn}$ & $6.44^{\mathrm{a}} \pm 0.10$ & $6.29^{\mathrm{a}} \pm 0.16$ & $10.24^{\mathrm{b}} \pm 0.45$ & $5.32^{\mathrm{a}} \pm 0.40$
\end{tabular}

Legend: Means (between the same elements from the different sites) within a row with the same letter are not significantly different. a, b, c $\mathrm{P}<0.05$ 
and Markovac $(\mathrm{P}>0.05)$. The concentrations of $\mathrm{Pb}$, $\mathrm{Cd}, \mathrm{Hg}$ and As were significantly lower in muscle tissue of the Prussian carp from Ocaga than concentrations of these metals from Grabovac, Markovac i Rabrovac. The major pollutants from these localities were $\mathrm{Fe}$ and $\mathrm{Zn}(\mathrm{P}<0.05)$.

The level of element bioaccumulation in fish tissues depends on various biotic and abiotic factors, such as fish biological habits, chemical form of metal in the water, water temperature, water $\mathrm{pH}$, concentration of dissolved oxygen in the water, as well as sex, age, body weight and physiological condition of fish (Has-Schön et al., 2015). The content of elements in fish tissues varies, and is most often examined in muscle tissue, gills, liver, digestive tract and kidneys. We decided to determine the contents of elements in fish muscle tissue because it is of the greatest interest due to its use in human nutrition, and it also speaks to the state of the environment. Additionally, the Prussian carp, as an omnivorous fish, is an excellent biological indicator of environmental pollution (Zrncic et al., 2013).

Lead in the Prussian carp muscle tissue, from fish landed from four investigated lakes south of Belgrade, showed the greatest variation among the examined elements. The lead content in the Prussian carp meat probably depends, to a large extent, on the catch location of these fish, and it was almost threefold greater in fish from two of the southern lakes than in the carp meat from the two other southern lakes. On the other hand, north of Belgrade, the lead content in the carp meat did not vary greatly between the lakes. The lowest lead content recorded in the muscle of locally-harvested carp was from the Danube upstream (west) from Belgrade, while similar levels as ours were found in muscle tissue of carp caught in the Danube downstream of Belgrade $\left(0.014 \mathrm{mg} \mathrm{kg}^{-1}\right.$; $0.048 \mathrm{mg} \mathrm{kg}^{-1}$, respectively) (Milanov et al., 2016, Ivanovic et al., 2016). All measured lead contents in fish meat from the Belgrade region in the current study were significantly below the MACs of $0.30 \mathrm{mg} \mathrm{kg}^{-1}$ (Official Gazette of RS, 2014, European Commission Regulation, 2006). Higher contents $\left(0.95-1.30 \mathrm{mg} \mathrm{kg}^{-1}\right)$ of lead were recorded in carp muscle tissue from Busko blato Lake in Bosnia and Herzegovina (Has-Schön et al., 2015), and such high levels indicate that the living world in lakes can be a good indicator of the state of the environment. High lead levels in the environment are most often derived from metallurgical fabricators, textile industry, battery production, gasoline additive (tetraethyl lead) and insecticides (based on lead arsenates). The high content of lead in the muscle tissue of all sorts of fish can be explained by their feeding habits, as they reside at the bottom and feed on benthic organisms. Therefore, the fish are in constant contact with sediment and accumulate a relatively high amount of elements that reliably reflect the ecological state of the water environment (Wei et al., 2014).

The highest content of cadmium was determined in the muscle tissue of Prussian carp caught from Lakes Rabrovac and Becmen, and these levels were significantly higher than in carp from Lake Ocaga. All mean levels of cadmium in carp meat were above the MACs of $0.050 \mathrm{mg} \mathrm{kg}^{-1}$ (Official Gazette of RS, 2014, European Commission Regulation, 2006). Lower concentrations of cadmium than ours were found in the muscle tissue of Prussian carp caught in a lake in Bosnia and Herzegovina, and in the muscle tissue of Prussian carp from the Neretva river, in the order of $0.01 \mathrm{mg}$ $\mathrm{kg}^{-1}$ and $0.045 \mathrm{mg} \mathrm{kg}^{-1}$, respectively (Has-Schön et al., 2015). Almost identical cadmium levels, 0.058 $\mathrm{mg} \mathrm{kg}{ }^{-1}$ to $0.067 \mathrm{mg} \mathrm{kg}^{-1}$, were determined in the muscle tissue of omnivorous fish from fishponds around Belgrade (Janjic et al., 2015). The high content of cadmium in fish muscle can be attributed to the migration of this elements from sludge to fish, because it is known that bottom-feeding fish looking for food plunge into sludge. This is particularly pronounced if cadmium is released from industrial systems such as those located near Belgrade, i.e., Obrenovac south, and Pancevo north of Belgrade, which can lead to high contents of metals like cadmium both in water and in living organisms including fish. Also, as cadmium is present in fertilizers (especially phosphate), and is an integral part of fungicide (in the form of cadmium succinate), increased cadmium content in muscle tissue of fish can be of plant origin and is due to agricultural activities near water (Dubovina et al., 2018). Cadmium accumulates at all levels of the food chain and its occurrence in the environment causes pollution of water and soil, and enters the food chain through the root of the plants (Galal, 1993). The cadmium levels obtained in our current study from the Belgrade region varied widely, indicating the current concentrations of this element could be increasing, and it would be useful to introduce cadmium monitoring in fish, rivers and sediments around Belgrade.

In all examined Prussian carp, mercury contents varied only slightly, except for fish from Lake Grabovac $\left(0.331 \pm 0.025 \mathrm{mg} \mathrm{kg}^{-1}\right)$, south of Belgrade. As with lead, larger variations in mercury were observed in fish from the southern lakes than in those from the northern lakes. In other recent 
research on mercury in Prussian carp muscle, in the Danube, upstream from Belgrade, higher mercury levels $\left(0.327 \pm 0.110 \mathrm{mg} \mathrm{kg}^{-1}\right)$ were established (Milanov et al., 2016). Also, in the Danube downstream of Belgrade, similar mercury concentrations $\left(0.24 \pm 0.05 \mathrm{mg} \mathrm{kg}^{-1}\right)$ to ours were recorded in the muscle tissue of omnivorous fish, which indicates that the location of the catch affects mercury levels in fish (Ivanovic et al., 2016). Regardless of the moderate or low level of contamination of these waters with mercury, the content of this elements can be significant in fish meat. This can be interpreted as reflecting the ability of mercury to concentrate in fish flesh. The biological regulation of mercury in fish and its detoxification is such that the content of mercury in fish increases mainly with the age, so the meat of older fish tends to have accumulated larger amounts of mercury. Increased mercury levels in the environment are mainly of anthropogenic origin and due to industrial discharges. Although mercury is one of the most toxic metals in the environment, in all our examined samples of fish meat, recorded concentrations were below the MACs prescribed (Official Gazette of RS, 2014, European Commission Regulation, 2006).

The highest concentrations of arsenic in Prussian carp muscle were found in fish from lakes north of Belgrade, except Lake Grabovac, and these levels were statistically significantly higher $(\mathrm{P}<0.01)$ than in fish from the lakes south of Belgrade. It is interesting to note that arsenic and mercury concentrations in the fish from the four lakes south of Belgrade decrease in the same order (Grabovac > Rabrovac $>$ Markovac $>$ Ocaga). On the other hand, muscle tissue of carp from a lake near Belgrade contained a proximate level of $0.378 \mathrm{mg} \mathrm{kg}^{-1}$ of arsenic (Janjic et al., 2015). We noticed dissipation of our established arsenic concentrations in the carp, indicating the catch location has an impact on the arsenic in muscle tissue of the fish.

Comparing copper concentrations in the fish, no statistically significant differences were found, although higher concentrations were measured in fish from northern lakes than in those from southern lakes. This uniformity of copper levels could be linked to the important role this metal plays in all living organisms, including fish. The copper contents in Danubian Prussian carp muscle were almost identical to ours and were in the interval $0.809 \mathrm{mg} \mathrm{kg}^{-1}$ to $0.824 \mathrm{mg} \mathrm{kg}^{-1}$ (Jovanovic et al., 2017).

Zinc and copper were present in muscle of Prussian carp from lakes south of Belgrade in decreasing concentrations in the order Ocaga >
Rabrovac $>$ Markovac $>$ Grabovac. The highest concentrations of zinc $\left(10.24 \pm 0.45 \mathrm{mg} \mathrm{kg}^{-1}\right)$ were in Prussian carp muscle from Lake Ocaga, and concentrations here were significantly higher $(\mathrm{P}<0.01)$ than in fish from other lakes. The zinc contents show that catch location has a major influence on the greatly differing content of this metal in the fish meat. Multiple-fold higher zinc concentrations were found in muscle tissue of Prussian carp $\left(82.5 \pm 2.0 \mathrm{mg} \mathrm{kg}^{-1}\right)$ and bream (62.5 $\left.\pm 1.3 \mathrm{mg} \mathrm{kg}^{-1}\right)$ compared to our results (Pantelica et al., 2012). Higher zinc concentrations were recorded in muscle tissue of Prussian carp from the Danube near Belgrade, with levels ranging from $10.26 \mathrm{mg} \mathrm{kg}^{-1}$ to $11.16 \mathrm{mg} \mathrm{kg}^{-1}$ (Jovanovic et al., 2017). Zinc in the environment most often comes from industrial zones, and in the Earth's crust, it is a constituent of rock, minerals and certain carbonate sediments.

Iron concentrations, regardless of the location of the catch, did not greatly vary in our Prussian carp muscle tissue. Iron concentrations were in the range of $7.00 \pm 0.14 \mathrm{mg} \mathrm{kg}^{-1}$ (Grabovac) to $7.76 \pm 0.27$ mg kg-1 (Becmen), and there were no statistically significant differences between lakes. Proximate iron contents in muscle tissue of Prussian carp from the Danube near Belgrade ranged from $7.25 \mathrm{mg} \mathrm{kg}^{-1}$ to $8.05 \mathrm{mg} \mathrm{kg}^{-1}$ (Jovanovic et al., 2017). Iron, copper and zinc do not have defined MACs in fresh fish meat in Serbia or the EU (EU Regulations, Regulation of Republic of Serbia).

\section{Conclusions}

The high concentrations of non-essential elements (cadmium) can be explained by anthropological influences, largely industrial development, discharge of waste water, and the subsequent increased element content in sewage sludge. On the other hand, the contents of lead, mercury and arsenic in fish muscle were below the MACs prescribed in Serbia and the EU. The Official Gazette of the Republic of Serbia does not define MACs for $\mathrm{Cu}, \mathrm{Fe}$ or $\mathrm{Zn}$ in fresh fish, so the results obtained by quantifying these metals can be interpreted freely. Results of this study show that continuous monitoring of the state of aquatic ecosystems is required, along with the introduction of efficient wastewater treatment and control of potential industrial polluters. On the territory of Belgrade and throughout Serbia, these necessary environmental protections are basic measures that would improve the existing situation in the water ecosystems of lakes near Belgrade that are important for fishing. 


\title{
Sadržaj elemenata u mišićnom tkivu babuške iz različitih jezera sa urbanog područja
}

\author{
Dragoljub Jovanović, Vlado Teodorović, Radmila Marković, Milena Krstić, Jelena Ćirić, Milan Ž. Baltić, \\ Branislav Baltić, Dragan Šefer
}

A p s tr a kt: Cilj ovog ispitivanja bio je da se utvrdi sadržaj pojedinih elemenata ( $\mathrm{Pb}, \mathrm{Cd}, \mathrm{Hg}, \mathrm{Fe}, \mathrm{Cu}, \mathrm{Zn}, \mathrm{As})$ u mišićnom tkivu babuške (Carassius auratus gibelio) iz sedam različitih jezera u regionu Beograda, Srbija. Koncentracije Pb, Hg i As u mišićnom tkivu ribe iz svih ispitivanih jezera bile su ispod maksimalno dozvoljenih novoa propisanih od strane Evropske unije (EU) $i$ maksimalno dozvoljenih koncentracija (MAC) za Srbiju. Kod svih ispitivanih riba, nivo Cd je bio iznad maksimalno dozvoljene koncentracije (0,05 $m g$ kg-1). Podaci o sadržaju elemenata u mišićnom tkivu riba istovremeno govore o bezbednosti ribe kao hrane i dobar su pokazatelj zagađenja životne sredine.

Ključne reči: Elementi, babuška, jezera, kontaminacija.

Disclosure statement: No pontentialpotential conflict of interest reported by authors.

Acknowledgments: This paper was supported by the Ministry of Education, Science and Technological Development, Republic of Serbia, via the project TR 31011 and TR 31034.

\section{Reference}

Andreji, J., Stranai, I., Massayi, P., \& Valent, M. (2006). Accumulation of some metals in muscles of five fish species from Lower Nitra River. Journal of Environmental Science and Health A, 41, 2607-2622.

Castro-Gonzalez, M. I., \& Mendez-Armenta, M. (2008). Heavy metals: Implications associated to fish consumption. Environmental Toxicology and Pharmacy, 26, 263-271.

Dubovina, M., Krcmar, D., Grba, N., Watson, M. A., Radjenovic, D., Tomasevic-Pilipovic. D., \& Dalmacija, B. (2018). Distribution and ecological risk assessment of organic and inorganic pollutants in the sediments of the transnational Begej canal (Serbia-Romania). Environ Pollution, 236, 773-784.

Elia, A. C., Dorr, A. J. M., \& Galarini, R. (2007). Comparison of Organochlorine Pesticides, PCBs, and Heavy Metal Contamination and of Detoxifying Response in Tissues of Ameiurus melas from Corbara, Alviano, and Trasimeno Lakes, Italy. Bullet of Environmental Contamination and Toxicology, 78, 463-468.

European Food Safety Authority, (2009). Scientific Opinion of the Panel on Contaminants in the Food Chain on a request from the European Commission on cadmium in food. The EFSA Journal, 980, 1-139.

European Commission Regulation, (2006). Setting maximum levels for certain contaminants in foodstuffs. Official Journal of the European Union, Commission Regulation No. 1881/2006/EC.

Galal Gorchev, H. (1993). Dietary intake, levels in food and estimated intake of lead, cadmium and mercury. Food Additve Contamination, 10, 115-128.
Has-Schön, E., Bogut, I., Vukovic, R., Galovic, D., Bogut, A., \& Horvatic, J. (2015). Distribution and age-related bioaccumulation of lead $(\mathrm{Pb})$, mercury $(\mathrm{Hg})$, cadmium (Cd), and arsenic (As) in tissues of common carp (Cyprinus carpio) and European catfish (Silurus glanis) from the Busko blato reservoir (Bosnia and Herzegovina). Chemosphere, 135, 289-296.

Ivanovic, J., Janjic, J., Baltic, M., Milanov, R., Boskovic, M., Markovic, R., \& Glamoclija, N. (2016). Metal concentrations in water, sediment and three fish species from the Danube River, Serbia: a cause for environmental concern. Environmental Science Pollution Results, 23, 17105-17112.

Janjic, J., Ivanovic, J., Markovic, R., Starcevic, M., Boskovic, M., Djordjevic, V., \& Baltic, M. (2015). Metal concentration in muscle tissue of carp and pike from different fish ponds in Belgrade area. Journal of Agriculture Science and Technology, 5, 429-436.

Jovanovic, D., Markovic, R., Teodorovic, V., Sefer, D., Krstic, M., Radulovic, S., Ivanovic Ciric, J., Janjic, J., \& Baltic, M. Z. (2017). Determination of heavy metals in muscle tissue of six fish species with different feeding habits from the Danube River, Belgrade - public health and environmental risk assessment. Environmental Science Pollution Results, 24, 11383-11391.

Kminkova, M., Winterová, R., \& Kucera, J. (2001). Fatty acids in lipids of carp (Cyprinus carpio) tissues. Czech Journal of Food Science, 19, 177-181.

Kosior, G., Samecka-Cymerman, A., \& Brudzinska-Kosior, A. (2018). Transplanted Moss Hylocomium splendens as a Bioaccumulator of Trace Elements from Different 
Categories of Sampling Sites in the Upper Silesia Area (SW Poland): Bulk and Dry Deposition Impact. Bullet of Environmental Contamination Toxicology, 101, 479-485.

Mayneris-Perxachs, J., Bondia-Pons, I., Serra-Majem, L., \& Castellote, A. I. (2010). Long-chain n-3 fatty acids and classical cardiovascular disease risk factors among the Catalan population. Food Chemistry, 119, 54-61.

Milanov, R., Krstic, M., Markovic, R., Jovanovic, D., Baltic, B., Ivanovic, J., Jovetic, M., \& Baltic, M. (2016). Analysis of heavy metals concentration in tissues of three different fish species included in human diet from Danube river, in the Belgrade region, Serbia. Acta Veterinaria-Beograd, 66, 89-102.

Official Gazette of RS, (2014). Rules on the maximum allowable residues of pesticides in food and animal feed which is determined by the maximum allowable amounts of residues of plant protection products (Official Gazette of RS, no. 29/2014, 37/2014 - isp., 39/2014 and 72/2014).
Pantelica A, Ene A, \& Georgescu II, (2012). Instrumental neutron activation analysis of some fish species from Danube River in Romania. Microchemistry Journal, 103, 142-147.

Sidhu, K. S. (2003). Health benefits and potential risks related to consumption of fish or fish oil. Regular Toxicoly Pharmacology, 38, 336-344.

Wei, Y. H., Zhang, J. Y., Zhang, D. W., Tu, T. H., \& Luo, L. G. (2014). Metal concentrations in various fish organs of different fish species from Poyang Lake, China. Ecotoxicology Environmental Safety, 104, 182-188.

Yoshizawa, K., Rimm, E. B., Morris, J. S., Spate, V. L., Hsieh, C. C., Spiegelman, D., Stampfer, M. J., \& Willet, W. C. (2002). Mercury and the risk of coronary heart disease in men. New England Journal of Medicine, 347, 1755-1760.

Zrncic, S., Oraic, D., Caleta, M., Mihaljevic, Z., Zanella, D., \& Bilandzic, N. (2013). Biomonitoring of heavy metals in fish from the Danube River. Environmental Monitoring Assessment, 185, 1189-1198. 